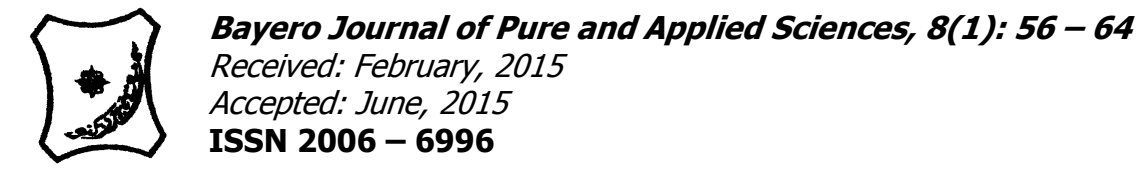

\title{
THE EFFECT OF AQUEOUS STEM BARK EXTRACT OF ERYTHRINAMILDBRAEDII ON CARBON TETRACHLORIDE INDUCED LIVER DAMAGE IN RATS
}

\author{
* Wudil, A.M and Sarki, S. I. \\ Department of Biochemistry, Bayero University, Kano- Nigeria. \\ *Correspondence author: amwudil@hotmail.com.
}

\begin{abstract}
This study evaluated the curative effects of aqueous stem bark extact of Erythrina mildbraedii in $\mathrm{CCL}_{4}$ induced liver damage. With the exception of group 1 (positive control), $\mathrm{CCL}_{4} \mathrm{was}$ administered at a dose of $150 \mathrm{mg} / \mathrm{kg}$ to groups II, III, IV and V.Administration of CCL $\mathrm{Caused}$ profound hepatic damage as indicated by elevation in serum levels of liver transaminases, alkaline phosphatase, total and direct bilirubin. There was depletion of serum proteins and albumin. Administration of aquoeus stem bark extract of Erythrina mildbraedii at daily oral doses of 50,100, $150 \mathrm{mg} / \mathrm{kg}$ reversed these biochemical aberrations to a significant level. The curative effects of stem bark extracts of Erythrina mildbraedii were further substantiated by histopathological examination of the liver hepatocytes. The result of the study suggested that aqueous stem bark extract of Erythrina mildbraedii posses hepatocurative effects.
\end{abstract}

Keywords: Carbontetrachloride, Erythrina mildbraedii, liver enzymes, hepatotoxicity.

\section{INTRODUCTION}

Liver is exposed to many potentially toxic substances via gastrointestinal tract from the diet, food additives, contaminants and drugs and is frequently a target in experimental animals. By virtue of its position, structure, function and biochemistry, the liver is especially vulnerable to damage from toxic compounds (Timbrell, 2009). As the major drug metabolizing and detoxifying organ in the body, the liver is subjected to potential damage from an array of pharmaceutical and environmental chemicals. Injury may result from direct toxicity via hepatic conversion of a xenobiotic to an active toxin or through immune mechanisms, usually by a drug or a metabolite acting as hapten to convert a cellular protein into an immunogen (Kumar et al., 2006).

Medicinal plantsare those plants that provide medicines to prevent disease, maintain health or cure sickness. In other word, these plants benefit virtually everyone on the earth. Plants provide the predominant ingredients of medicines in most traditional systems of healing and have been the sour ce of inspiration for several new drug researches to major pharmaceutical companies (Maiti et al., 1999). The plants that posses therapeutic properties or exact beneficial pharmacological effects on the body are generally designated as "medicinal".

Medicinal plants are of great importance to the health of individuals and communities. The medicinal value of these plants lies in some chemical substances that produce a definite physiological action on the human body. The most important of these bioactive constituents of plants are alkaloids, tannins, flavonoids, and phenolic compounds (Hill, 1993). They play a significant role in providing primary health care services to rural people. They serve as therapeutic agents as well as important raw materials for the manufacture of traditional and modern medicines.

Erythrina mildbraedii (Minjirya in hausa)is a tree that grow up to $30 \mathrm{~m}$ in height and is native to West Africa. Erythrina species produce many secondary metabolites, some of which have a function of defence systems against pathogenic fungi and bacteria (Karthishwaran et al., 2010). Ethnobotanical discovery process of sub-Saharan Erythrina has resulted in promising biological activities (Kone et al., 2004; Nguyen et al., 2010).

Many Erythrina species showed real potential for fighting pathogenic agents associated with public health problems in sub-Saharan Africa. For e.g. multidrug resistant pathogens are responsible for therapeutic failures (Kone and Kamanzi, 2009). This situation is serious because microbial infections are most frequent opportunistic diseases occurring during HIV/AIDS which affected many people in Africa. Moreover, during this infection, cancer and cardiovascular diseases, oxidative stress and generating free radicals is known to cause damage to cell and immune system of patients. Scientists are searching for new molecules that could provide alternative to conventional treatments (Coulidiati et al., 2011).

High incidence of cancer, inflammation, and cardiovascular diseases are attributed to oxidative stress. Some Sub-Saharan Erythrina species are used by traditional practitioners to treat cancer and inflammation. These plants were investigated for cancer chemo protective agents and inhibitors of enzyme borne diseases. 
Bajopas Volume 8 Number 1June, 2015

The studies were carried out on enzymes such as phospholipase C gamma 1,diacylglycerol acyltransferase (DGAT), protein tyrosin phosphatase 1 $B(P T B$ 1B), ERK kinase,5-lipooxygenase and 15lipooxygenase. Inhibitors of these enzymes are proposed in the therapy of obesity, type 2 diabetes and cancer. Ethylacetate extract of Erythrina mildbraedii stem bark inhibited PTB 1B ( $\mathrm{Na}$ et al., 2006; Jang et al., 2008). Erythrina mildbraedii extract showed anti-inflammatory activity and radical scavenging activity in 1, 1-Diphenyl-2-picrylhydrazyl (DPPH) assay (Njamen et al., 2003).

Carbon Tetrachloride once used extensively in dry cleaning and even as an anesthetic is primarily hepatotoxic, causing two different types of pathological effect. Its toxicity has been studied both from the biochemical and pathological viewpoints, and therefore the data available provide particular insight into mechanisms of toxicity. Carbon tetrachloride is a simple molecule which, when administered to a variety of species, causes centrilobular hepatic necrosis (zone 3) and fatty liver. It is a very lipid-soluble compound and is consequently well distributed throughout the body, but despite this, its major toxic effect is on the liver, irrespective of the route of administration (Timbrell, 2009). It is a classic example of a chemical activated by cytochrome $\mathrm{P} 450$ to form a highly reactive free radical. First, $\mathrm{CCl}_{4}$ is converted to the trichloromethyl radical $\left(\mathrm{CCl}_{3}{ }^{\circ}\right)$ and then to the trichloromethylperoxy radical $\left(\mathrm{CCl}_{3} \mathrm{O}_{2}{ }^{\circ}\right)$. Such radicals are highly reactive and generally have a small radius of action. For this reason the necrosis induced by $\mathrm{CCl}_{4}$ is most severe in the centrilobular liver cells that contain the highest concentration of the $\mathrm{P}_{450}$ isozyme responsible for $\mathrm{CCl}_{4}$ activation. Typically free radicals may participate in a number of events, such as covalent binding to lipids, proteins, or nucleotides as well as lipid peroxidation.is now thought that $\mathrm{CCl}_{3}$, which forms relatively stable adducts, is responsible for covalent binding to macromolecules, and the more reactive $\mathrm{CCl}_{3} \mathrm{O}_{2}$. , which is formed when $\mathrm{CCl}_{3}$ reacts with oxygen, is the prime initiator of lipid peroxidation (Hodgson, 2010). The research work was carried out to evaluate the effect of aqueous stem bark extract of Erythrina mildbraedii on carbon tetrachloride induced hepatotoxicity in rats.

\section{MATERIALS AND METHODS}

\section{Plant identification and Collection}

Erithrina mildbraedii stem bark was collected from Song local Government Area of Adamawa State. It was identified and authenticated by a Botanist at the Botany unit of the Faculty of Science, Bayero University Kano, Nigeria

\section{Extraction of Plant Materials}

The stem bark of the plant collected was carefully washed in clean water, and then dried at room temperature. They were pulverized to coarse powder and distilled water $\left(500 \mathrm{~cm}^{3}\right)$ was added to $100 \mathrm{~g}$ of the powdered stem bark in a conical flask. The content of the flask was then shaken and the top was covered with aluminium foil and kept for 48 hours. The extract was then obtained by filtration using whatman No 1filter paper. The filtrate was dreid and then reconstituted for administration.

\section{Experimental Animals}

Twenty four (24) white albino rats (weighing 160 to $250 \mathrm{~g}$ ) were purchased from the Animal Room of the Biological Sciences Department, Bayero University,Kano. The rats were maintained under standard laboratory conditions and were allowed free access to both food and water throughout the period of the experiment.

The volume $\left(\mathrm{cm}^{3}\right)$ of the stem bark aqueous extract given to each rat was determined by its weight and required dose as follows:

Volume administered $\left(\mathrm{cm}^{3}\right)=$

weight of rat $(\mathrm{kg}) X$ Required dose $(\mathrm{mg} / \mathrm{kg})$

Concentration of the extract $\left(\mathrm{mg} / \mathrm{cm}^{3}\right)$

\section{Experimental Design}

Twenty four (24) experimental rats were divided into eight groups of three (3) rats each. Liver toxicity was induced in groups II - VIII using $\mathrm{CCl}_{4}$ according to Alhassan et al., (2009). administered)

Group I: normal rats (No extract, no $\mathrm{CCl}_{4}$ Control)

Group II: $\mathrm{CCl}_{4}$ administered no extract (Test

Group III: were administered with aqueous stem bark extract of Erithrina mildbraedii

(Dose; $50 \mathrm{mg} / \mathrm{kg}$ orally. Once daily for two weeks).

Group IV: were administered with aqueous stem bark extract of Erithrina mildbraedii daily for two weeks). (Dose; $100 \mathrm{mg} / \mathrm{kg}$ orally. Once

Group V: were administered with aqueous stem bark extract of Erithrina mildbraedii

(Dose; $150 \mathrm{mg} / \mathrm{kg}$ orally, once daily for two weeks).

Group VI: were administered with aqueous stem bark extract of Erithrina mildbraedii

(Dose; $50 \mathrm{mg} / \mathrm{kg}$ orally, once daily for four weeks).

Group VII: were administered with aqueous stem bark extract of Erithrina mildbraedii (Dose; $100 \mathrm{mg} / \mathrm{kg}$ orally, once daily for four weeks).

Group VIII: were administered with aqueous stem bark extract of Erithrina mildbraedii four weeks) 


\section{Blood and Tissue Samples Collection}

Rats in groups I and II were sacrificed after $48 \mathrm{hrs}$ of $\mathrm{CCl}_{4}$ administration to confirm lipid peroxidation and liver damage. Groups III- V were sacrificed after two weeks of extract administration, while groups VI- VIII were sacrificed after 4 weeks of extract administration. The liver from both control and test animals were excised, sliced and fixed in $10 \%$ formaldehyde solution and used for histological examination.

\section{Biochemical Analysis}

Blood samples were collected, allowed to clot and centrifuged at $2000 \mathrm{rpm}$ for $10 \mathrm{~min}$ to obtain the serum samples. For each serum sample, the level of alanine aminotransferase(ALT), aspartate amino transferase (AST) were determine using the method of Reitman and Frankel (1957), alkaline phosphatase (ALP) using the method of Rec (1972), direct bilirubin(DB) and total bilirubin (TB) by the method of Jendrassik and Grof (1938), total protein(TP) using the method of Tietz (1995) and albumin (ALB) using the method of Grant ( 1987) were analyzed in order to assess liver function.

\section{Histopathology}

Histological examinations were conducted using the method of Auwioro (2010). The liver tissues were fixed in multiple baths of ethanol, embedded in paraffin,sectioned and stained with hematoxylin and eosin.

\section{Statistical Analysis}

The data was statistically analysed using one-way analysis of variance (ANOVA) with $\mathrm{P}$ value $<0.01$ considerd to be significant. Graphpad Instat 3 software (2000). Version 3.05, Graphpad Inc was used for all the analysis.

\section{RESULTS}

The hepatocurative activity of aqueous stem bark extract of Erythrina mildbraedii was evaluated in the experimental animals two weeks and four weeks after inducement of liver damage.Table 1 shows the mean serum level of liver indices (AST, ALT, ALP, ALB, DB, TB and TP), for group of rats 48 hours after administration of $150 \mathrm{mg} / \mathrm{Kg} \mathrm{CCl}$ (Group II) and compared to that of normal control Group I which is to confirm inducement of hepatotoxicity and lipid peroxidation by the $\mathrm{CCl}_{4}$.

The result obtained showed a significant increase $(P<0.01)$ in the mean serum level of AST,ALT, ALP, DB and TB while that of TP and ALB decreases in the test control group when compared with the normal control rats.

After two weeks of oral administration of aqueous stem bark extract of Erythrinamildbraedii at a daily dose of $50 \mathrm{mg} / \mathrm{kg}$ only the mean serum level of ALP significantly decreased $(P<0.01)$ even though the level of AST, ALT, TB, DB decreased while that of ALB and TP increased but showed no significant difference $(P<0.01)$ when compared with test control groups. However the groups administered with a daily dose of 100 and $150 \mathrm{mg} / \mathrm{kg}$ had their mean serum levels of AST, ALT, ALP, DB and TB decreases significantly $(P<0.01)$ when compared to test control rats but still higher than that of the normal control rats while that of ALB significantly increased $(P<0.01)$ when compared with test control rats but lower than that of the normal control groups. The decrease in the mean serum levels of AST, ALT, ALP, DB, and TB and increase in the level of ALB was found to be dose dependent.

After four weeks of oral administration of aqueous stem bark extract of Erythrina mildbraedii the mean serum level of AST,ALT,ALP,DB and TB significantly decreased $(P<0.01)$ when compared with test control groups while that of ALB and TP increased significantly $(P<0.01)$ when compared to test control groups (Table 2 ). The mean serum level returned to near normal irrespective of the dose administered.

Plate 1of the histopathology result showed section of liver of normal rats with hepatocytes arranged in cord radiating from central venules. Plate 2 showed area of the liver with necrosis, fibrosis and degeneration of hepatocytes due to damage caused by $\mathrm{CCl}_{4}$ administration. Plate 3 showed section of the liver area with fibrosis after administration of $50 \mathrm{mg} / \mathrm{kg}$ of the extract for two weeks. Plate 4 and 5 showed cross section of the liver with fat cells after administration of $100 \mathrm{mg} / \mathrm{kg}$ and $150 \mathrm{mg} / \mathrm{kg}$ of the extract for two weeks. Plates 6, 7 and 8 showed no significant pathology, they showed hepatocytes arranged in cord radiating from central venules after administration of varing doses of the extract for four weeks. 
Table 1: Effects of oral administration of aqueous stem bark extract Erythrina mildbraedii(ASBEEM) on serum biochemical indices of CCl $_{4}$-induced hepatotoxicity in rats after two weeks.

\begin{tabular}{|c|c|c|c|c|c|c|c|}
\hline Groups/Dose(mg/kg) & AST(U/L) & ALT(U/L) & ALP(U/L) & TP(g/L) & $\operatorname{ALB}(g / L)$ & DB(Umol/L) & TB(Umol/L) \\
\hline I (Normal rats) & $23.33 \pm 1.53$ & $12.00 \pm 1.00$ & $110.33 \pm 1.53$ & $67.33 \pm 2.08$ & $43.33 \pm 5.51$ & $7.70 \pm 1.15$ & $18.33 \pm 0.75$ \\
\hline II $\mathrm{CCl}_{4}(150 \mathrm{mg} / \mathrm{kg})$ & $60.00 \pm 2.65^{*}$ & $44.00 \pm 6.25 *$ & $273.67 \pm 4.93 *$ & $37.33 \pm 3.51 *$ & $25.33 \pm 5.51 *$ & $20.40 \pm 0.78 *$ & $37.10 \pm 2.44 *$ \\
\hline III ASBEEM $(50 \mathrm{mg} / \mathrm{kg})$ & $44.67 \pm 4.04$ & $29.00 \pm 6.00$ & $245.00 \pm 3.61^{c}$ & $43.67 \pm 6.66$ & $33.67 \pm 2.31$ & $12.87 \pm 0.85$ & $27.87 \pm 1.57$ \\
\hline IV ASBEEM $(100 \mathrm{mg} / \mathrm{kg})$ & $41.00 \pm 1.00^{a}$ & $24.67 \pm 1.53^{b}$ & $191.67 \pm 12.74^{c}$ & $51.33 \pm 2.08$ & $38.00 \pm 1.73^{\mathrm{e}}$ & $10.87 \pm 1.16^{f}$ & $25.50 \pm 0.89^{g}$ \\
\hline V ASBEEM $(150 \mathrm{mg} / \mathrm{kg})$ & $32.00 \pm 2.00^{\mathrm{a}}$ & $19.00 \pm 1.00^{b}$ & $177.00 \pm 1.00^{c}$ & $52.00 \pm 4.36$ & $37.33 \pm 2.08^{\mathrm{e}}$ & $11.60 \pm 0.98^{f}$ & $21.07 \pm 2.01^{\mathrm{g}}$ \\
\hline
\end{tabular}

Results are expressed as mean \pm SD for three determinations, $\mathrm{n}=3$

Values with asterisk are significantly different at $\mathrm{P}<0.01$ when compared with normal rats.

Values in the same column bearing similar superscript are significantly different at $\mathrm{P}<0.01$ when compared with the test control groups

\begin{tabular}{|c|c|c|c|c|c|c|c|}
\hline Groups/Dose(mg/kg) & AST(U/L) & ALT(U/L) & $\operatorname{ALP}(\mathbf{U} / L)$ & $\operatorname{TP}(g / L)$ & ALB(g/L) & DB(Umol/L) & TB(Umol/L) \\
\hline I (Normal rats) & $23.33 \pm 1.53$ & $12.00 \pm 1.00$ & $110.33 \pm 1.53$ & $67.33 \pm 2.08$ & $43.33 \pm 5.51$ & $7.70 \pm 1.15$ & $18.33 \pm 0.75$ \\
\hline II $\mathrm{CCl}_{4}(150 \mathrm{mg} / \mathrm{kg})$ & $60.00 \pm 2.65^{*}$ & $44.00 \pm 6.25^{*}$ & $273.67 \pm 4.93 *$ & $37.33 \pm 3.51 *$ & $25.33 \pm 5.51^{*}$ & $20.40 \pm 0.78^{*}$ & $37.10 \pm 2.44 *$ \\
\hline III ASBEEM $(50 \mathrm{mg} / \mathrm{kg})$ & $23.67 \pm 4.04^{h}$ & $14.00 \pm 2.00^{\mathrm{i}}$ & $123.00 \pm 11.79^{j}$ & $60.33 \pm 2.52^{k}$ & $40.00 \pm 1.00^{\prime}$ & $9.77 \pm 0.57^{\mathrm{m}}$ & $21.47 \pm 2.08^{n}$ \\
\hline IV ASBEEM $(100 \mathrm{mg} / \mathrm{kg})$ & $25.67 \pm 3.01^{h}$ & $13.80 \pm 0.72^{i}$ & $117.00 \pm 4.36^{j}$ & $59.33 \pm 2.30^{k}$ & $40.67 \pm 2.52^{\prime}$ & $9.90 \pm 1.35^{\mathrm{m}}$ & $22.60 \pm 1.90^{n}$ \\
\hline V ASBEEM $(150 \mathrm{mg} / \mathrm{kg})$ & $26.00 \pm 1.00^{h}$ & $12.27 \pm 0.58^{i}$ & $113.67 \pm 7.76^{j}$ & $66.33 \pm 3.79^{k}$ & $41.00 \pm 8.00^{\prime}$ & $9.53 \pm 2.55^{\mathrm{m}}$ & $22.17 \pm 2.82^{n}$ \\
\hline
\end{tabular}

Results are expressed as mean \pm SD for three determinations, $n=3$

Values with asterisk are significantly different at $\mathrm{P}<0.01$ when compared with normal rats.

Values in the same column bearing similar superscript are significantly different at $\mathrm{P}<0.01$ when compared with test control group 
Plate 1 shows photomicrograph of cross section of liver of normal rats. Plate 2 showed the section of the liver administered with $150 \mathrm{mg} / \mathrm{kg}$ body weight of $\mathrm{CCl}_{4}$. Plates 3, 4 and 5 showed cross section of the liver administered with varying doses of ASBEEM for two weeks. Plates 6,7 and 8 showed cross section of the liver treated with varying doses of ASBEEM for four weeks.

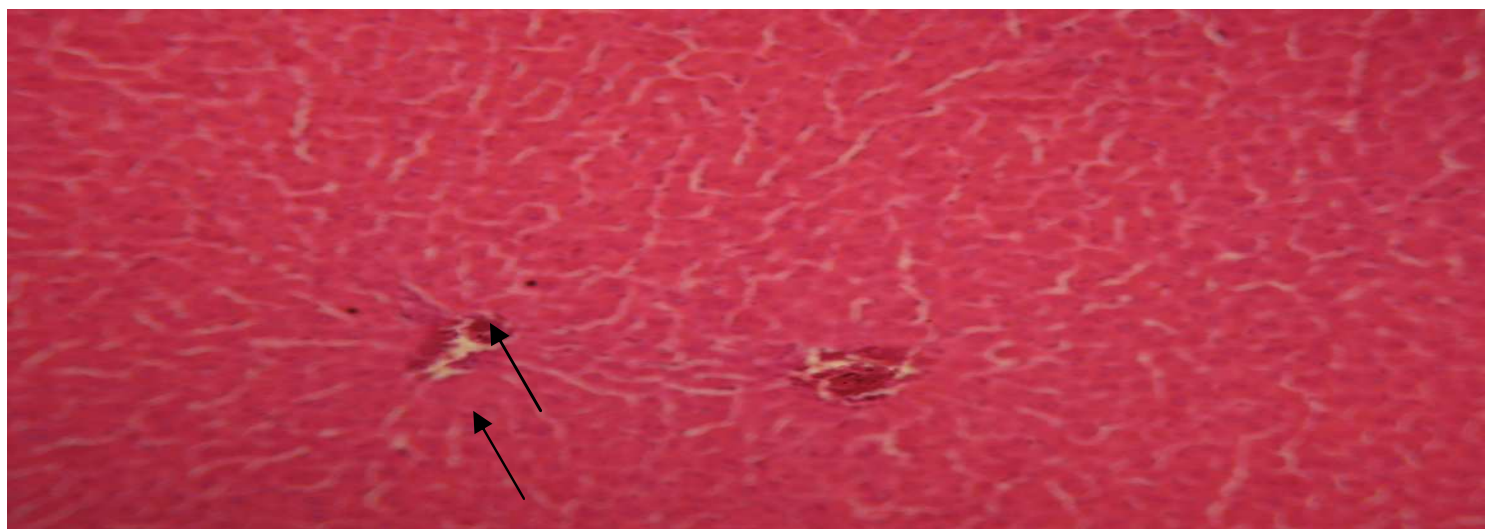

Plate1: Section of the liver of normal rats shows hepatocytes arranged in cord radiating from central venules. $\mathrm{H}$ \& E STAIN X 10

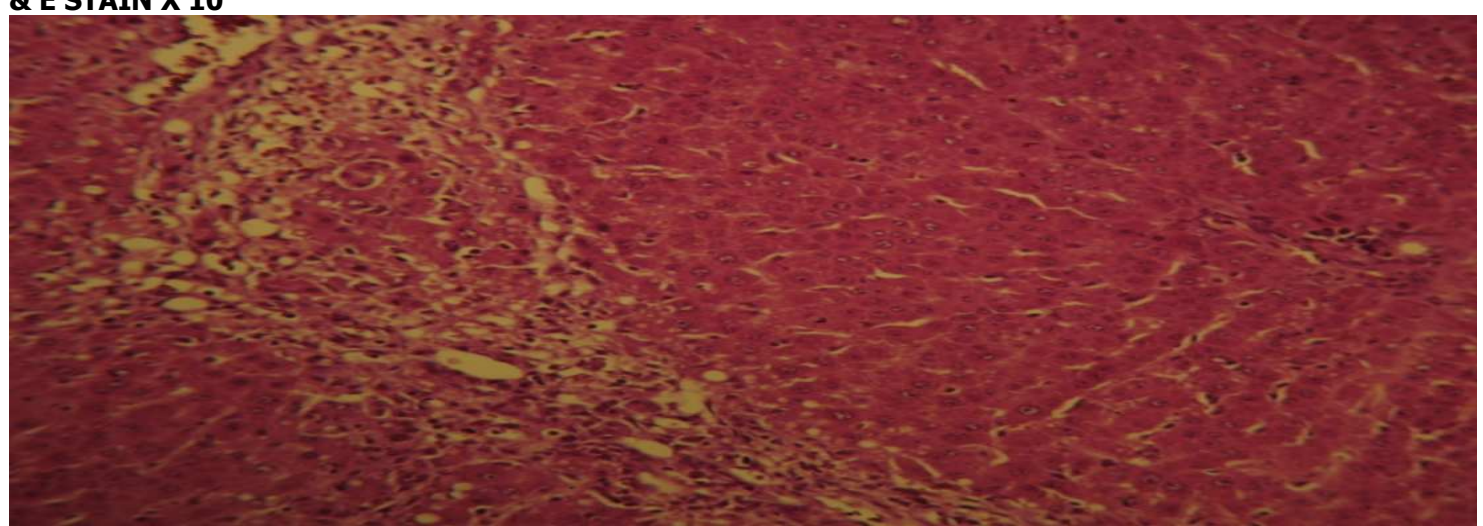

Plate 2: Section of the liver shows area of necrosis, fibrosis and degeneration of hepatocytes after $\mathrm{CCl}_{4}$ $150 \mathrm{mg} / \mathrm{kg}$ administered to induce liver damage. H \& E STAIN X 10

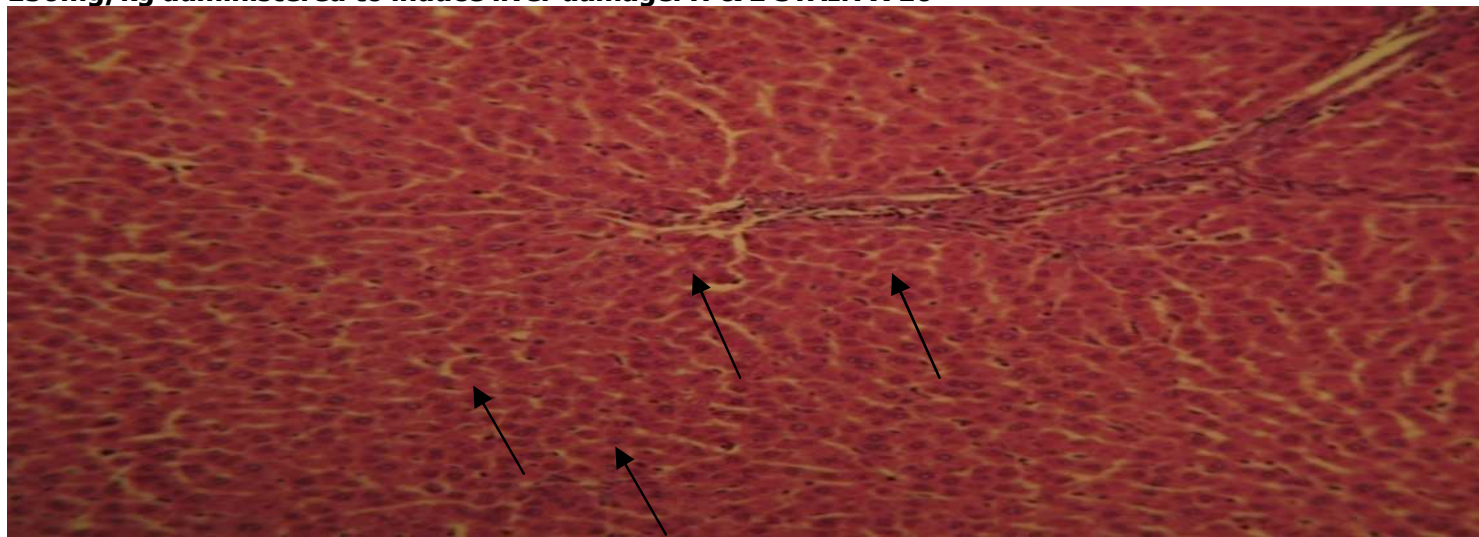

Plate 3: Section of the liver shows area of fibrosis after ASBEEM $50 \mathrm{mg} / \mathrm{kg}$ administered for two weeks. H \& E STAIN X 10

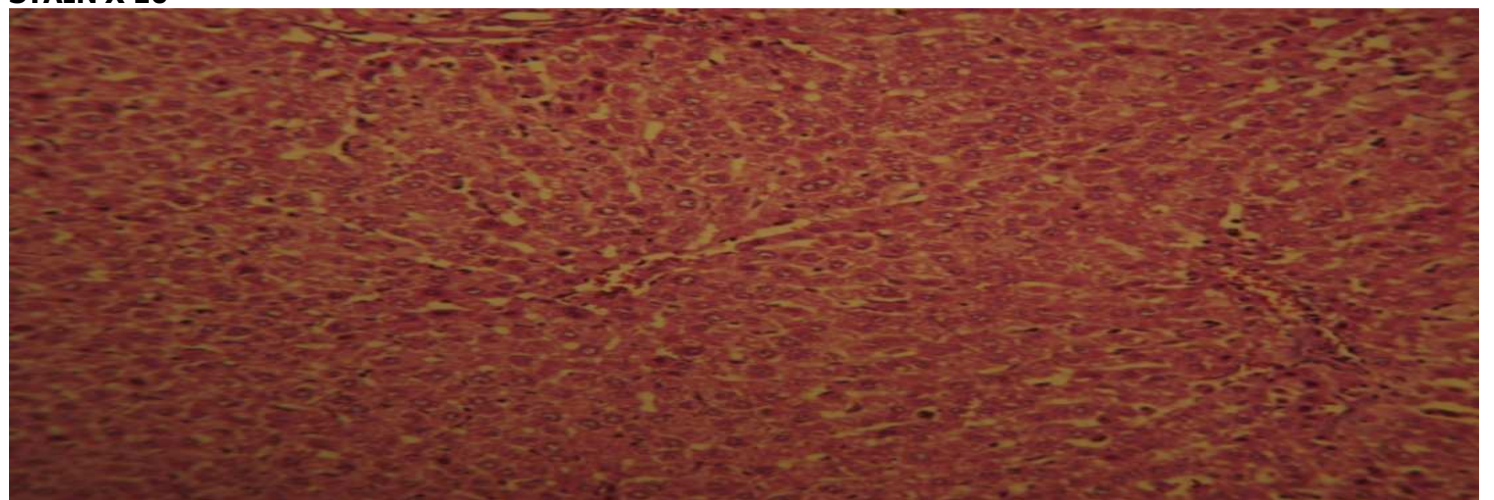

Plate 4: Section of the liver area of fat cells after ASBEEM $100 \mathrm{mg} / \mathrm{kg}$ administered for two weeks. H \& E STAIN X 10 


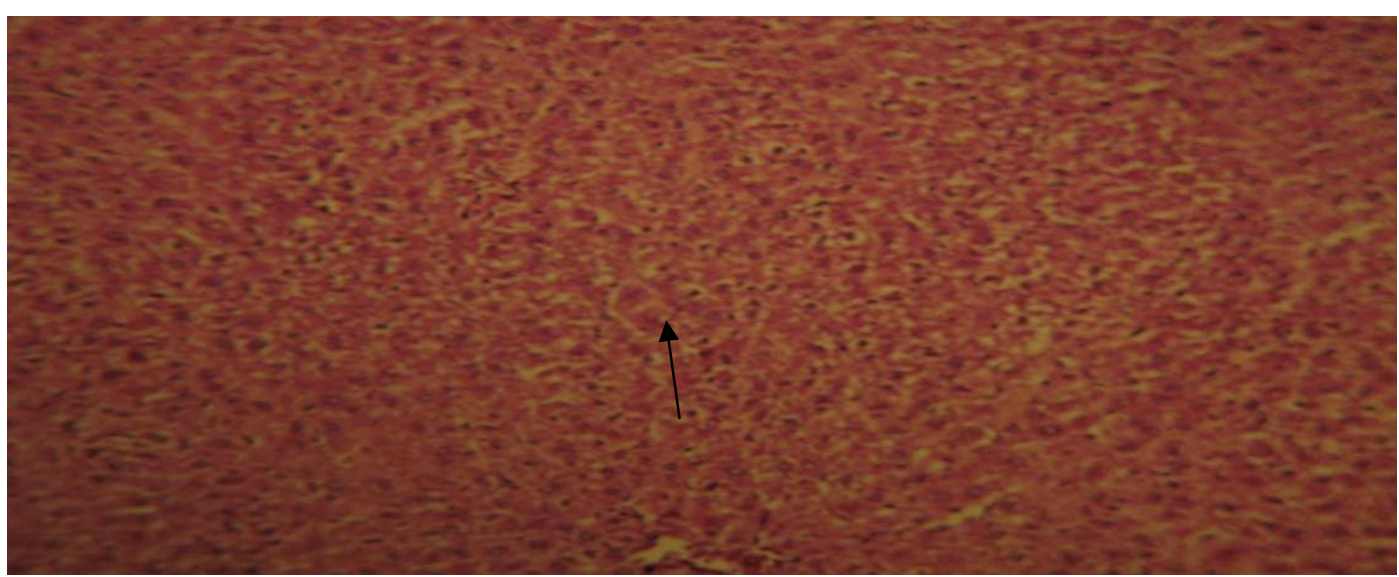

Plate 5: Section of the liver area of fat cells after ASBEEM $150 \mathrm{mg} / \mathrm{kg}$ administered for two weeks. H \& E STAIN $\mathbf{X} 10$

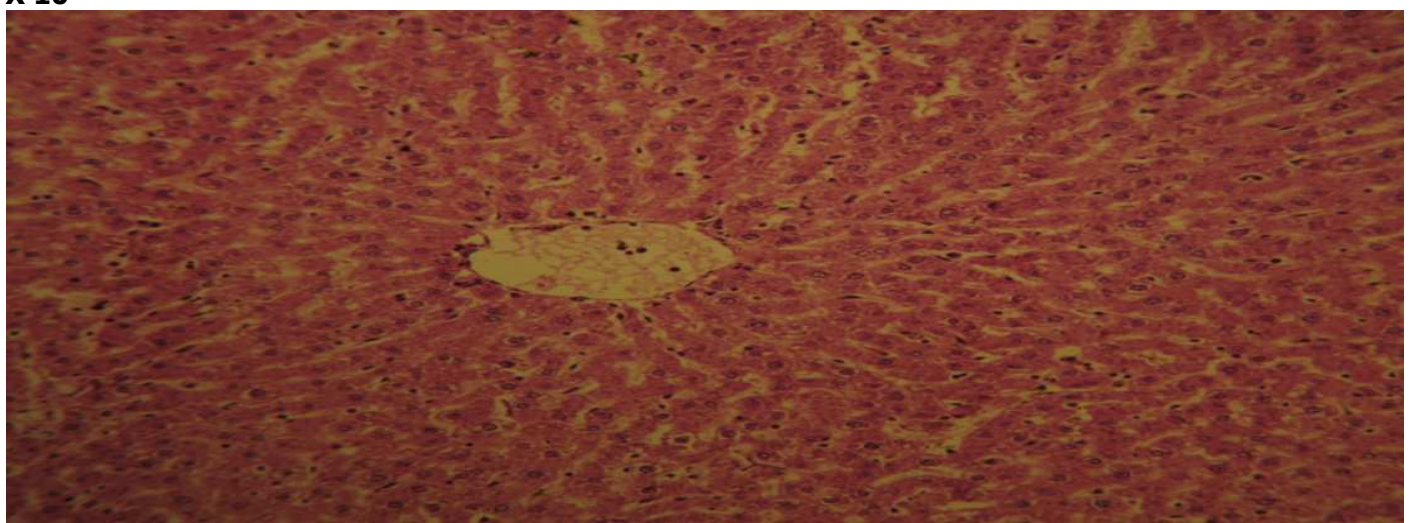

Plate 6: Section of the liver shows no significant pathology, they showed hepatocytes arranged in cord radiating from central venules after ASBEEM $50 \mathrm{mg} / \mathrm{kg}$ administered for four weeks. H \& E STAIN X 10

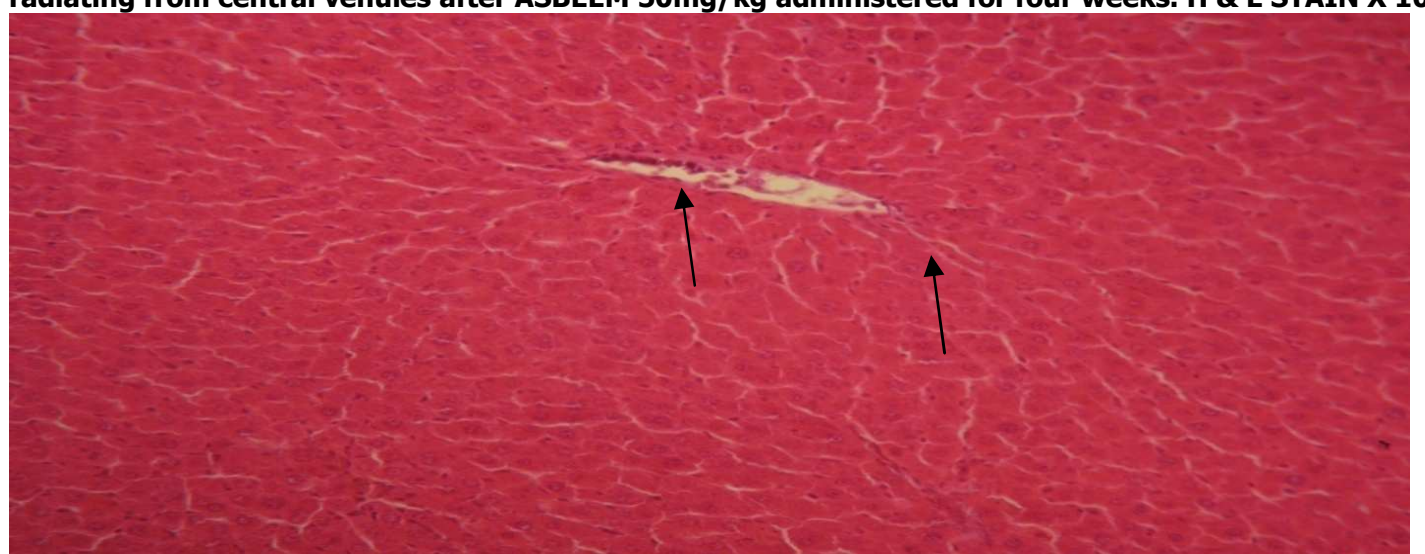

Plate 7: Section of the liver shows no significant pathology, they showed hepatocytes arranged in cord radiating from central venules after ASBEEM $100 \mathrm{mg} / \mathrm{kg}$ administered for four weeks. H \& E STAIN X 10

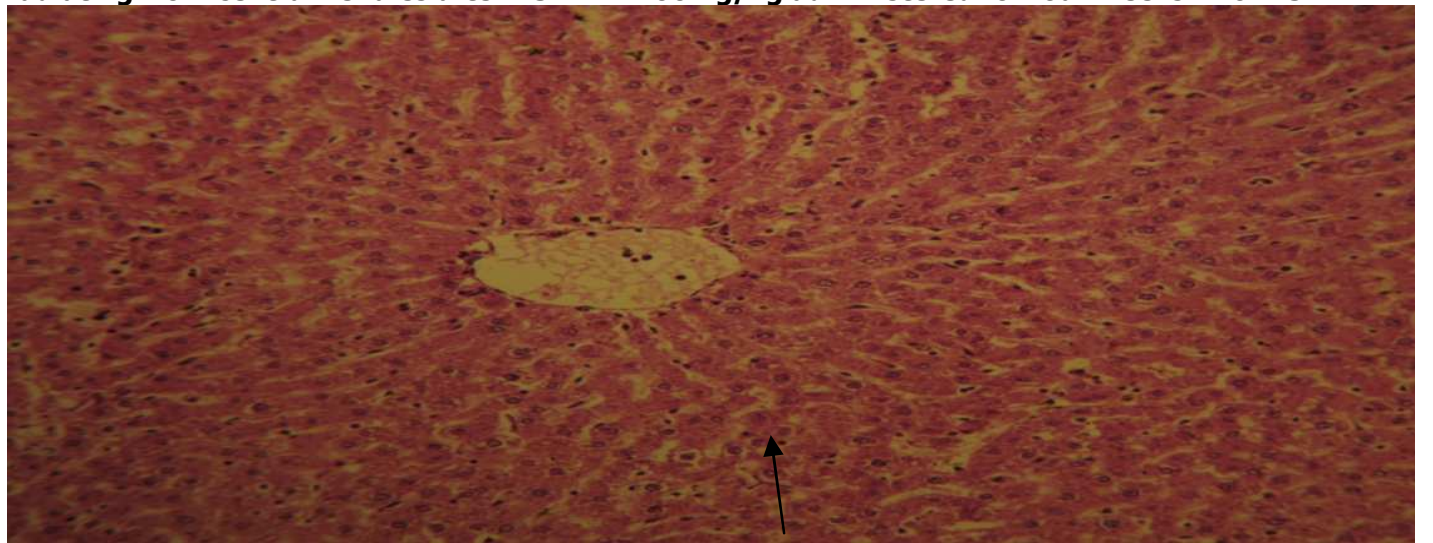

Plate 8: Section of the liver shows no significant pathology, they showed hepatocytes arranged in cord radiating from central venules after ASBEEM $150 \mathrm{mg} / \mathrm{kg}$ administered for four weeks. H \& E STAIN X 10 


\section{DISCUSSION}

Liver injury induced by $\mathrm{CCl}_{4}$ is the best-characterized system of xenobiotic -induced hepatotoxicity and is a commomly used model for the screening of medicinal and toxicological activities of drugs (Brautbar and Williams, 2002; Brent and Rumack, 1993). Information in Table 1showed that $\mathrm{CCl}_{4}$ administration caused significant elevation of ALT, AST, ALP, direct bilirubin and total bilirubin by inducing hepatic damage in test control group when compared to normal group.

Hepatic injury caused by $\mathrm{CCl}_{4}$ is due to the generation of its reactive trichloromethyl radical $\left(\mathrm{CCl}_{3}{ }^{*}\right)$ by the action of microsomal Cytochrome $\mathrm{P}_{450}$ enzyme (CYP2E11). This highly reactive free radical readily reacts with molecular oxygen to form the trichloro methyl peroxy radical $\left(\mathrm{CCl}_{3} \mathrm{O}_{2}\right)$. Both trichloro and peroxy radicals can bind to cellular proteins and lipids, initiating lipid peroxidation and liver damage Direct and total bilirubin levels were elevated in $\mathrm{CCl}_{4}$ treated rats, caused either due to an increased production, decreased secretion from the liver or blockage of the bile ducts (Bun et al., 2006). Bilirubin is derived from the regular degradation of haemoglobin from the red blood cells and excreted from the liver in the bile. It is a chemical normally present in the blood in small amounts and used by the liver to produce bile. When the liver cells are damaged, they may not be able to excrete bilirubin in the normal way, causing a build-up of bilirubin in the blood and extracellular fluid (Saukonen et al., 2006).

Liver is an important site for the synthesis of many serum proteins and the levels of serum proteins are decreased in hepatic diseases. The oxidative damage of some amino acids is considered as the major cause of metabolic dysfunction in hepatic damage (Bandyopadhyay etal., 1999). Serum albumin is the main plasma protein produced in the liver, a clinically useful indicator of hepatic synthetic function (Sturgill and Lambert 1997)

Liver injury is associated with a decline in the concentration of serum albumin, and hypoalbuminemia has been considered to be consequence of a decreased rate of hepatic synthesis of the essential protein in both humans and animals (Ruot etal., 2002). Accordingly, the serum albumin and total protein levels were determined in the present study. The $\mathrm{CCl}_{4}$-treated rats exhibited significantly lower serum total protein and albumin levels compared with the normal control rats. However, administration of ASBEEM increased these serum levels to a normal control range. This suggests that ASBEEMpossesses ability to promote protein synthesis that plays a significant contributory role in hepatoprotective activity, which in turn has been shown to enhance proliferative process and the production of hepatocytes (Awang, 1993).

\section{REFERENCES}

Alhassan, A. J., Sule, M. S., Hassan, J. A., Baba, B. A. and Aliyu, M. D. (2009). Ideal Hepatotoxicity Model Using $\mathrm{CCl}_{4}$. Bay. J. App.Sci. 2(2): 185187.

Auwioro, O.G. (2010). Histochemistry and Tissue Pathology: Principles and Techniques. $2^{\text {nd }}$
(Recknagal et al., 1989).When cell membrane of hepatocytes is damaged, a variety of enzymes such as ALT, AST and ALP are released into the blood from the cytosol (Mitra et al., 1998). A rise in serum transaminases is a sensitive indicator of damage to hepatocytes even if there is no evident hepatic impairment. The increase in ALT, AST and ALP activities observed in the test control group is an indication of the extensive liver damage induced by $\mathrm{CCl}_{4}$. Administration of ASBEEM causes a significant and dose dependent decrease in the level of AST, ALT and ALP when compared to test control group after two weeks, however administration of ASBEEM after four weeks completely abolished the alterations induced by $\mathrm{CCl}_{4}$ in activities of serum alkaline phosphatase, alanine aminotransferase and asparate aminotransferase (Table 2). These suggests that aqueous stem bark extract of Erythyrina mildbraedii might possesses hepatoprotective effect.

The histopathology studies of liver showed fatty degeneration and loss of normal structure of hepatocytes in $\mathrm{CCl}_{4}$ administered rats, in comparison with the normal control. The extract treated groups showed regeneration of hepatocytes and reduction of fatty changes in hepatocytes. It has been reported by previous findings that $\mathrm{CCl}_{4}$ causes necrosis (Sun et al., 2001), fibrosis (Natsume et al., 1999), mononuclear cell infiltration (Natsume et al., 1999), steatosis and degeneration of hepatocytes, increase in mitotic activity (Teocharis et al., 2001) and cirrhosis (Zalatnai et al.,1991) in liver. It has also been reported that $\mathrm{CCl}_{4}$ causes apoptosis in the liver (Shi et al., 1998; Sun et al., 2001).Therefore, histopathological findings in the liver due to $\mathrm{CCl}_{4}$ administration are in agreement with previous studies that $\mathrm{CCl}_{4}$ may cause fatty liver due to disturbance in normal lipid homeostasis by an increase in the esterification of free fatty acids to form triglycerides, phospholipids and other fatty acid esters with increase in cholesterol synthesis (Boll et al., 2001)..

Phytochemical screening of ASBEEM has revealed the presence of alkaloids, flavonoids, steroids, glycosides, saponins and tannins. Phytoconstituents like the flavonoids (Baek et al., 1996), saponins (Tran et al., 2001) and alkaloids (Vijayan et al., 2003) are known to possess hepatoprotective activity. The presence of flavanoids in our extract may be responsible for its antioxidant effect and thus hepatoprotective activity.

\section{CONCLUSION}

The results of this study showed the hepatocurative effect of aqueous stem bark extract of Erythrina mildbraedii on $\mathrm{CCl}_{4}$ induced liver damage. The hepatocurative effect was found to be dose dependent and increases with duration of treatment with the extract.

Edition. University Press Delta State University, Abraka Nigeria.Pp. 561-568.

Awang, D. (1993). Milk Thistle .Can Pharmacol J.23, 749-754.

Bandyopadhyay, U., Dipak, D. and Banerji, R. K. (1999). Reactive Oxygen Species. Oxidative Damage and Pathogenesis. Curr. Sci. 5. 658. 
Boll, M., Weber, L.W.D., Becker, E., and Stampfi, A. (2001). Mechanism of Carbon Tetrachloride Induced Hepatotoxicity. Hepatocellular Damage by Reactive $\mathrm{CCl}_{4}$ Metabolites. $Z$. Naturforsch. 56(C):649-659.P

Brautbar, N. and Williams, J. (2002). $2^{\text {nd }}$ Industrial Solvent and Liver Toxicity: Risk Assessement, Risk Factors and Mechanisms.Intl.J. Hyg. Environ.Health .205:479-491.

Brent, J.A. and Rumack,B.H.(1993). Role of Free Radicals in Toxic Hepatic Injury ii. Free Radical Biochemistry .J. Toxicol. Clin. Toxicol, 31:173-196.

Bun, S.S., Bun, H., Guedon, D., Rosier C., and Ollivier E. (2006).Effect of Green Tea Extract on Liver Functions in Wister Rats. Food Chem. Toxicol.44:1108-1113.

Coulidiati, T.H., Millogo-Kone, H., Lamien-Meda, A., Yougbare-Ziebrou, M., Millogo-Rasolodimby J. and Nacoulma, O.G. (2011). Antioxidant and Bacterial Activities of Two Combretum Species from Burkina Faso. Res. J. Med. Plant.5:42-53.

Fromentry, B. and Pessayre, D. (1995): Inhibitional Mitochondrial B-Oxidation as a Mechanism of Hepatotoxicity. Pharmacol. Ther.67: 101154.

Grant, G. H. (1987). Amino Acids and Proteins, In Fundamentals of Clinical Chemistry, Tietz N. W. Editor, $3^{\text {rd }}$ Edition, Wb Saunders Company Philadelphia USA, 328-329.

Haouzi, D., Lekehal, M., Moreau, A., Moulis, C., Feldman, G., Robin, M.A., Letteron, P., Faug, D., and Pessayre, D. (2000): Cytochrome P450- Generated Reactive Metabolites Caused MitochondrialPermeability Transition, Caspase Activation and Apoptosis in RatHepatocytes. Hepatology, 32: 303-311.

Hill, A.R. (1993). Medicinal Plants and Traditional Medicine in Africa.J. Integr. Med. 39:42-45

Hodgson, E., (2010).A Text Book of Modern Toxicology. $4^{\text {th }}$ Edition. John Wiley and Sons, Inc., New Jersey.Pp.263-272,275-302.

Jang, J., Na, M., Thuong, P.T., Njamen, D. and Mbofor J.T. (2008).Prenylated Flavonoid with PTP1b Inhibitory Activity from Root Bark of Erythrina Mildbraedii. Chem. Pharm. Bull.56:85-88.

Jendrassik, L. and Grof. P. (1938). Colorimetric Method for Determination of Serum Bilurubin Biochem. Z. 297: 81.

Karthiswaran, S., Mirunalini, Dhamodharan, G., Krishnaveni, M., and Arulmozhi, V. (2010).Phytochemical Investigation of Methanolic Extract of the Leaves of Pergularia Daemia. J. Biol. Sci.10:242-246.

Kato, H. and Nakazawa, Y. (1987):The Effect Of $\mathrm{CCl}_{4}$ on the Enzymatic Hydrolysis of Cellular Triacylglycerol in Adult Rat Hepatocytes in Primary Monolayer Culture. Biochem. Pharmacol. 36: 1807-1814.

Kone, W. M., Atindehou, K. K., Terreaux, C., Hostettmann, K., Traore, D., and Dosso, M. (2004).Traditional Medicine in North Cote-
D'ivoire: Screening of 50 Medicinal Plantsfor Antibacterial

Activity.J.Ethnopharmocol.93:43-49.

Kone, M. W. and Kamanzi Atindehou, K. (2009). West African Plants and Related Phytocompounds with Anti-Multidrug-Resistance Activity in: New Strategies Combating Bacterial Infection.Wiley-Blackwell, Weinheim,Germany. Pp. 136-164.

Kumar, V., Abbas, A. K. and Faustso, N. (2006).Robbins and Cotran Pathological Basis ofDiseases. $7^{\text {th }}$ Edition Saunders Elselvier, New Delhi Pp.413.

Mitra, S. K., Venkataraganna, M. V., Sundaran, R., and Gopumadhavan S. (1998). Protective Effect of HDs-03, a Herbal Formulation against Various Hepatotoxic Agents in Rats. J. Ethnopharmacol. 63:181-186.

Na, M., Jang, J., Njamen, D., Mbafor, J.T., Fomum, Z. T., Kim, B.Y., Oh, W. K., and Ahn, J. S. (2006).Protein Tyrosine Phosphate-1b Inhibitory Activity of Isophenylated Falconoid Isolated from Erythrina Mildbraedii. J. Nat. Prod. 69: 1572-1576.

Natsume, M., Tsuji, H., Harada, A., Akiyama, M., Yano, T., and Ishikura, H. (1999). Attenuated Liver Fibrosis and Depressed Serum Albumin Levels in Carbon Tetrachloride-Treated IL-6-Deficient Mice. $J$ Leukoc Biol.66:601-8.

Nguyen, P. H., Na, M., Dao, T. T., Ndinteh, D. T., and Mbafor J. T. (2010). New Stilbeniod With Inhibitory Activity On Viral Neuraminidases From Erythrina Addisonaea. .Bioorg. Med. Chem. Lett.20:6430-6344.

Njamen, D., Talla, E., Mbafor, J. T., Fomum, Z. T., Kamanyi, A., Mbanya, J. C., Cerda-Nicolas, M., Giner, R. M., Recio, M. C., and Rios, J. L. (2003). Anti-Inflammatory Activity of Erycristagallin A Pterocarpene Eur. J. Pharmacol. 468: 67-74.

Paradisi, L., Losa, G. A. and Dianzani, M. U. (1985):Enzymatic Biophysical and Ultrastructural Changes of Plasma Membranes in Chemically Induced Rat Hepatocytes. Cell Biochem. Func. 4: 259-26.

Poli, G., Chiarpotto, E., Albano, E., Cottalasso, D., Nanni, G., Marinari, U. M., Bassi, A. M. and Dianzani, M.U. (1985): Carbon Tetrachloride- Induced Inhibition of Hepatocyte LipoproteinSecretion: Functional Impairment of Golgi Apparatus in the Early Phases of Such Injury. Life Sci., 36: 533539.

Rec, G. S. (1972).Colorimetric Method For Serum Alkaline Phosphatase Determination. J. Clin. Biochem. 10(2): 182.

Recknagal, R. O., Glenda, E. A., Dolak, Jr J. A., and Walter, R. L. (1989). Mechanism of Carbon Tetrachloride Toxicity.Pharmacol. Ther., 43.139-154

Reitman, S. and Frankel, S. (1957). A Colorimetric Method for the Determination of Serum Glutamic Oxaloacetate and Glutamic Pyruvic Transaminase. Amer.J . Clin . Patho. 28:56. 
Ruot, B., Bechereau F., Bayle G., Breuille, D. and Obled, C. (2002). Albumin Synthesis in Humans Immediately Following the Administration of Endotoxin. Clin Sci.102, 107-114,

Saukkonen, J. J, Cohn D. L., Jasmer R.M, Schenker S. and Jereb J. A., (2006).An Official ATS Statement: Hepatotoxicity of Antituberculosis Therapy. Am J. Respir CritCareMed 174: 935-952.

Sturgill, M.G. and Lambert G.H. (1997). Xenobiotic Induced Hepatotoxicity Mechanisms of Liver Injury and Methods of Monitoring Hepatic Functions. Clin Chem 43:8(B), 1512-1526.

Sun, F., Hamagawa, E., Tsutsui, C., Ono, Y., Ogiri, Y., and Kojo, S. (2001). Evaluation of Oxidative Stress during Apoptosis and Necrosis Caused by Carbon Tetrachloride in Rat Liver. Biochem Biophys Actu.1535:186-91.

Teocharis, S. E., Margeli, A. P., Skaltsas, S. D., Spiliopoulou, C. A., and Koutselinis, A. S. (2001) Induction Of Metallothionein In The Liver Of Carbon Tetrachloride Intoxicated Rats: An Immunohistochemical Study. Toxico 161:129-38.

Tietz, N. W. (1995). Clinical Guide to Laboratory Tests. $3^{\text {rd }}$ Edition W.B. Saunders Company, Philadelphia USA. Pp. 518-519.

Timbrell, J. A. (2009). Principle of Biochemical Toxicology. $4^{\text {th }}$ Edition. School of Pharmacy Kings College London. Informa Healthcare, New York Pp.1-10,308-345. 